\title{
Study of skin neoplasms in a university hospital: integration of anatomopathological records and its interface with the literature*
}

\author{
Hudson Dutra Rezende ${ }^{1}$, Ana Paula Moura de Almeida ${ }^{2}$, Eduardo Shimoda ${ }^{3}$ Ana Carolina Xavier \\ Milagre $^{1}$, Liana Moura de Almeida ${ }^{2}$
}

DOI: http:/ / dx.doi.org/10.1590/abd1806-4841.20197357

\begin{abstract}
BACKGROUND: Skin cancer is a highly prevalent condition with a multifactorial etiology resulting from genetic alterations, environmental and lifestyle factors. In Brazil, among all malignant tumors, skin cancers have the highest incidences. Овјестіvе: To retrospectively evaluate the incidence, prevalence and profile of basal cell carcinoma, squamous cell carcinoma and cutaneous melanoma in Campos dos Goytacazes and region.

MetHODS: In total, 2,207 histopathological reports of a local reference hospital were analyzed between January 2013 and December 2015, of which 306 corresponded to the neoplasms studied.

RESULTS: Of the 306 reports evaluated, 232 basal cell carcinomas (75.9\%), 55 squamous cell carcinomas (18\%) and 19 cutaneous melanomas $(6.5 \%)$ were identified. The face was the most involved anatomical site $(58.8 \%)$ and women (51\%) were the most affected gender. The temporal analysis revealed a decrease in the overall incidence of 3.4\% from 2013 to 2014 and $5.4 \%$ from 2014 to 2015 . There was a $10.1 \%$ increase in basal cell carcinomas and 38\% in melanomas in this period; however, there was a decrease in the number of squamous cell carcinomas of $14.8 \%$ during the studied years.

StUdy LimitaTions: Some samples of cutaneous fragments had no identification of the anatomical site of origin.

CONCLUSION: Research that generates statistical data on cutaneous tumors produces epidemiological tools useful in the identification of risk groups and allows the adoption of more targeted and efficient future prevention measures.
\end{abstract}

Keywords: Carcinoma, basal cell; Carcinoma, squamous cell; Health services research; Melanoma

\section{INTRODUCTION}

Skin cancer is a multifactorial disease that results mainly from genetic alterations, environmental factors and life style. ${ }^{1}$ Basal cell carcinoma (BCC) is the most common human neoplasm and its incidence has been increasing in all countries at a rate of 3 to $7 \%$ per year, configuring a public health problem. ${ }^{2,3}$ In Brazil, among all malignant tumors, skin cancer appears with the highest incidence. ${ }^{4}$

Squamous cell carcinoma (SCC) is the second most common skin cancer and is classified as a nonmelanoma skin cancer, as basal cell carcinoma; together they correspond to $95 \%$ of all malignant skin tumors. ${ }^{5,6}$ Despite the existence of still unknown risk factors in the genesis of nonmelanoma skin cancers, their relationship with chronic sun exposure has been proven. ${ }^{7,8}$

In general, most skin cancers have a good prognosis, with cure rates above $95 \%$ of the cases when diagnosed early and adequately treated. ${ }^{9}$ However, cutaneous melanoma, a tumor arising from melanocytes, deserves attention in this context due to its high metastatic potential and mortality. ${ }^{9-12}$

Statistical data from the National Cancer Institute, 2016, revealed an estimated 175,760 new cases of nonmelanoma skin cancers, with 80,850 of those in males and 94,910 in females, besides

\footnotetext{
Received 18 June 2017.

Accepted 29 November 2017.

* Work conducted at Hospital Escola Álvaro Alvim, Campos dos Goytacazes (RJ), Brazil.

Financial support: None.

Conflict of interest: None.

1 Program of Medical Residency in Dermatology, Hospital Escola Álvaro Alvim, Campos dos Goytacazes (RJ), Brazil.

Service of Dermatology, Hospital Escola Álvaro Alvim, Campos dos Goytacazes (RJ), Brazil.

Program of Post-Graduation, Master's and PhD in Regional Planning/City Management, Universidade Cândido Mendes, Campos dos Goytacazes (RJ), Brazil.
}

MAILING AdDREsS:

Ana Paula Moura de Almeida

E-mail: medpaula@yahoo.com.br 
5,670 new cases of cutaneous melanoma for the same period. This confirms the relevance of statistical analyses for primary skin tumors because they provide epidemiological tools useful in the identification of risk subgroups and in the promotion of prevention as a unique strategy in this context.

\section{METHODS}

This is an epidemiological, descriptive and retrospective study, conducted based on the manual analysis of histopathology files of a university hospital in Campos dos Goytacazes, State of Rio de Janeiro. The objective of the study were malignant skin neoplasms, basal cell and squamous carcinomas and cutaneous melanoma in particular. The data collected were initially grouped into plain Microsoft Excel spreadsheets and subsequently converted into graphic designs by the Sistema de Análises Estatísticas e Genéticas - SAEG, version 9.1.

Histopathology reports of incisional and excisional skin biopsies performed by dermatologists, general and plastic surgeons in our service and other smaller institutions that have us as a reference, as well as a small amount of samples collected in clinics and private practices from January 2013 to December 2015 were analyzed. In total, 2,207 files were evaluated by dermatology residents in approximately 44 hours.

In regard to the items proposed for the explanation of this study, we selected: age group (in decades), gender, period to be analyzed (in years) as well as the types of skin cancer, if basal cell or squamous cell carcinoma or melanoma, with all other excluded from the sample. The affected anatomical site was also addressed in this study and defined in seven areas of interest, namely: scalp, face, cervical region, upper limbs, lower limbs, trunk and genital region, of which the first five were listed as photoexposed.

\section{RESULTS}

Of the 2,207 histopathological reports analyzed, a sample of 306 cases $(13.86 \%)$ represented the skin cancers selected for this study. Of those, 232 cases of BCC (75.9\%), 55 of SCC (18.0\%), and 19 of cutaneous melanomas $(6.5 \%)$ were registered and the ratio of 1 malignant skin neoplasm for each 7.21 files reviewed was found (Graph 1).

Overall, the involvement of anatomical sites was varied, with most cases occurring on the face (58.8\%), followed by the trunk with $18.7 \%$, and lastly by the lesions diagnosed on the scalp, with only $1.7 \%$. Upper limbs, lower limbs, cervical and genital region were also affected, but in lower proportions (Graph 1).

The temporal analysis of the study shown on graph 2 revealed a decrease in the incidence of $3.4 \%$ and $5.4 \%$ from the first to the second year (2014) and from that to the third (2015), respectively. It was also observed in the same display that females (51.0\%) were slightly more affected than males $(49.0 \%)$ and that the incidence increases linearly from the fourth to the seventh decade of life, where most cases were registered (27.6\%). Only $9.4 \%$ of the patients were elderly, aged 80 years or older.

The cross-sectional view of this study, considering its start and finish (first and third years), revealed a $10.1 \%$ increase in the number of new BCC cases and 3.8\% for melanoma, that achieved a percentage almost twice as high in this period. In contrast, there was a linear decrease in SCC cases for less than half $(14.8 \%)$ from 2013 to 2015.

In regard to the development of nonmelanocytic tumors on photoexposed areas, BCC was the most prevalent, with more than $85 \%$ of the cases diagnosed in areas submitted to actinic effect, and the face was the most affected area (69.5\%). Similarly, $67.9 \%$ of all SCCs also appeared on sun exposed skin and the face $(30.5 \%)$ was again the most affected site. Cutaneous melanoma presented an in-

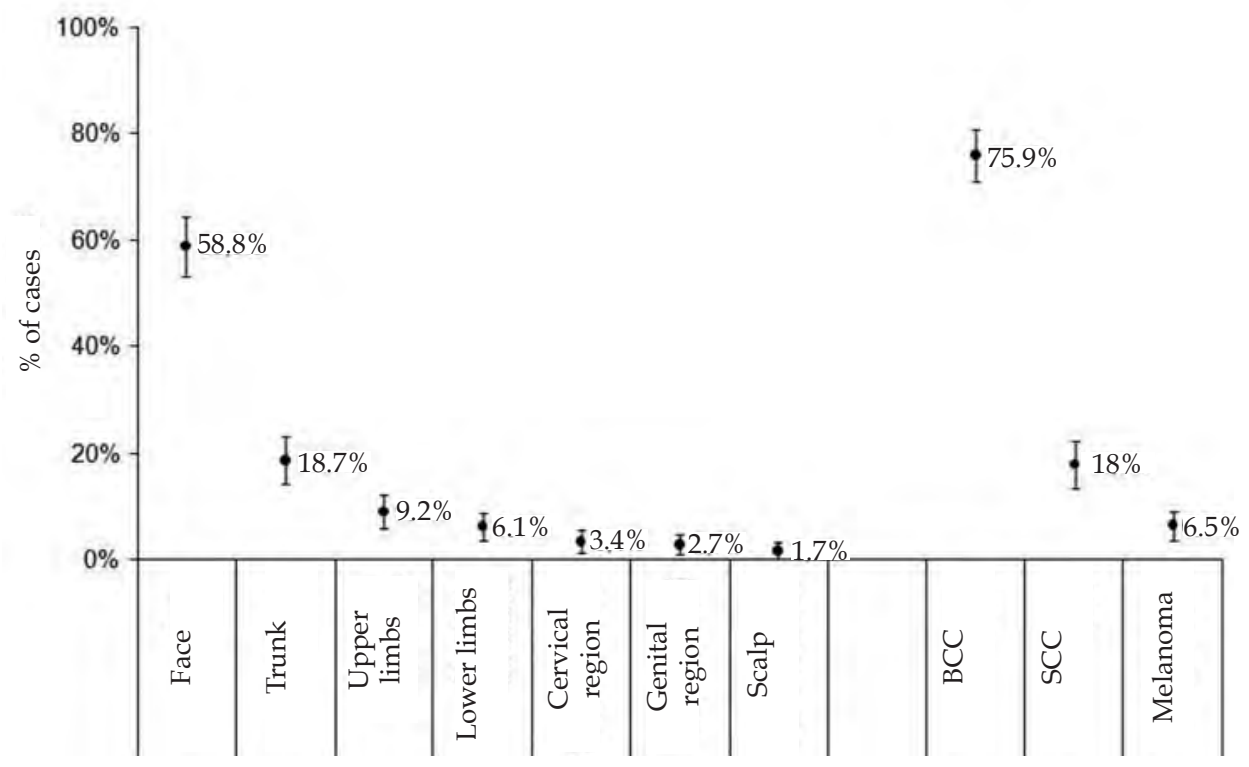

Graph 1: Prevalence of cutaneous neoplasms by subtype and anatomical distribution 

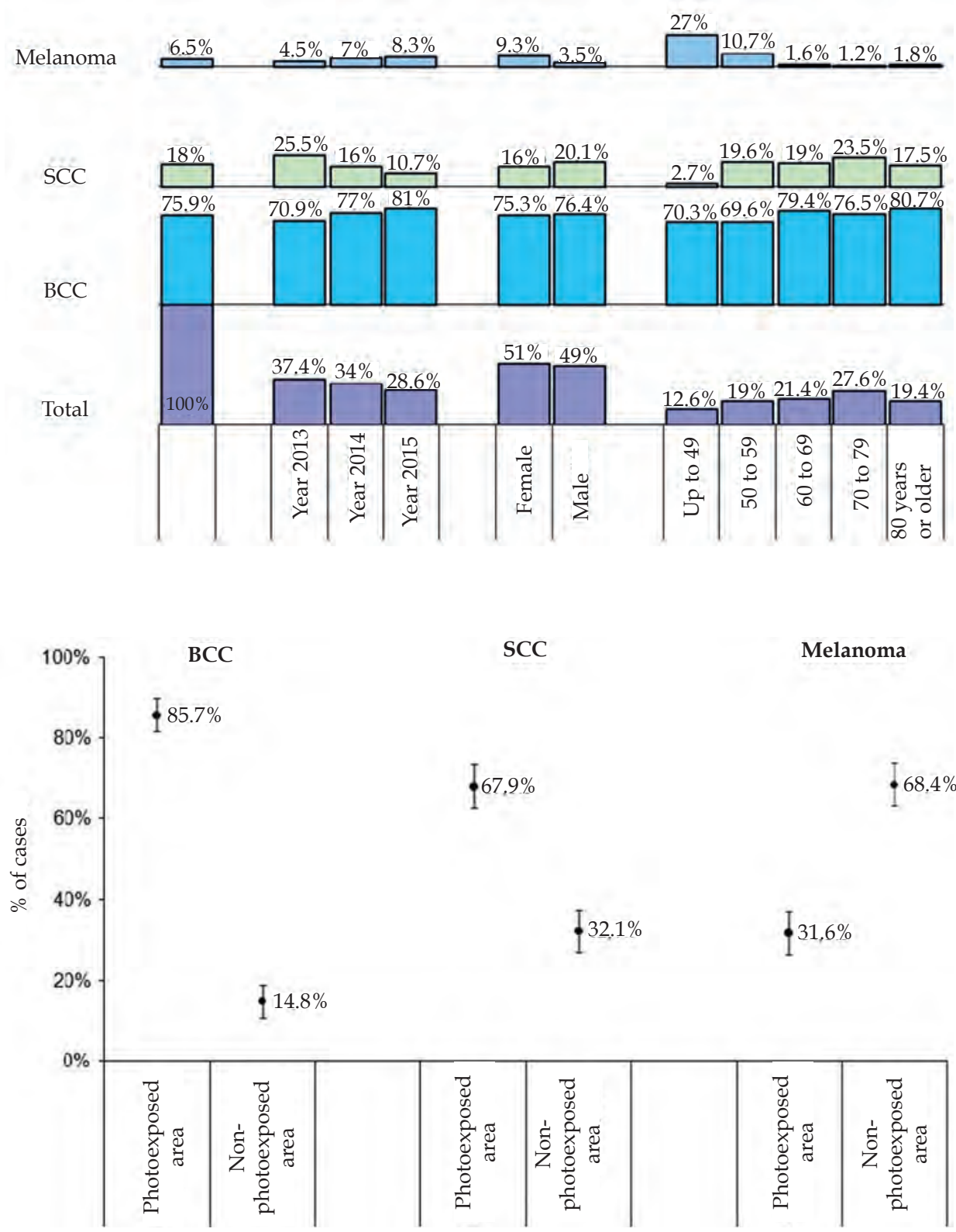

GraPH 2: Distribution of malignant cutaneous neoplasms according to the timeline of the study (in years), gender and age group
GraPH 3: Prevalence of cutaneous tumors in photoexposed and non-photoexposed areas version of this pattern: $68.4 \%$ were excised from areas commonly sun protected, as shown in graph 3.

Still regarding the body areas involved, the prevalence of BCC and SCC were similar since both affected the face and trunk as the preferred sites; the latter was also the most affected area by cutaneous melanomas (63.2\%). Virtually all tumors diagnosed on the scalp (3.8\%) were SCC and no melanoma was found on this site (Graph 4).

\section{DISCUSSION}

The study sample reveals, although superficially, the epidemiological profile of the most common types of skin cancer with a retrospective analysis of a university hospital in Campos dos
Goytacazes and surroundings. At the time of the research, it can be said that the institution had a reference role for many local services because it is the only service in the city with a practicing dermatopathologist, absorbing simple and particularly clinically atypical cases, what makes this analysis a potential mirror of the reality.

As announced by the broad existing literature on the prevalence of malignant skin tumors, BCC is the most frequent subtype and corresponds to $70-80 \%$ of all cases. ${ }^{13}$ Data from this study confirm general statistics with 232 BCC cases $(75.9 \%)$ and reaffirm the expected ration of four to five BCCs to each SCC. ${ }^{14}$ For each melanoma, 11.6 BCCs were reported, datum that is also consistent with the literature and determines an approximate ratio of ten BCCs for each melanoma. ${ }^{14}$ 


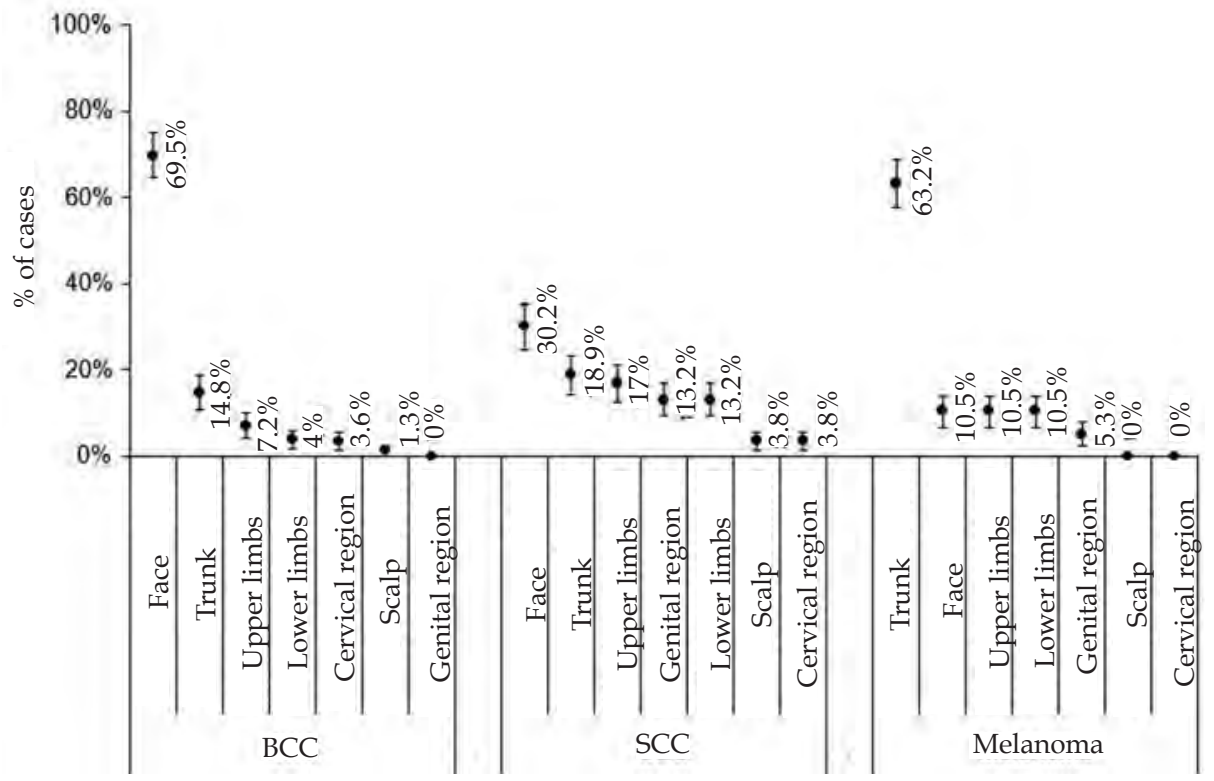

Graph 4: Cutaneous neoplasms according to the type and most commonly involved body areas
The decrease in the overall incidence of skin cancers in the period analyzed was due to the decrease in number of SCCs. This event is partially related to the improved approach to pre-cancerous lesions, particularly actinic keratoses, and also in situ neoplasms (Bowen's disease), with the comprehensive use of cryotherapy in our service over the past six to seven years. It is well known that cryotherapy with liquid nitrogen is a destructive procedure and highly effective, with cure rates between 75 and $99 \% .^{15}$

The age group with highest incidence of BCC was older than 80 years $(80.7 \%)$. More than half of BCC cases occurs between 50 and 80 years and its incidence increases with advancing age. ${ }^{13}$ It is also expected, as seen in this study, a higher involvement in males than females, probably due to professional reasons linked to excessive sun exposure. ${ }^{16}$

The prevalence of nonmelanocytic tumors in photoexposed areas confirms the important role of ultraviolet radiation in the genesis of these neoplasms and, in general, it is believed that for mela- noma personal or family history represents the most important risk factor. ${ }^{4,17}$ In this investigation, the higher number of melanomas diagnosed in photo protected areas $(68.4 \%)$ goes against this rationale and endorses the epidemiology published by Kraemer in 1994, in a study of 5,884 melanoma cases, of which $55 \%$ had a primary site on non-photoexposed areas and $45 \%$ in photoexposed areas. ${ }^{10}$

\section{CONCLUSION}

Retrospective statistical studies are a major tool for the detection of regional profiles of tumor involvement and facilitate the study and criticism of diagnostic and therapeutic methods present in a certain region or service. By enabling the epidemiological analysis of skin tumors in our region, detailed by gender, age group, anatomical site, subtype of cutaneous neoplasm and incidence variation over the years, this study substantiates the development of new actions of promotion of health and enable possible populational interventions better oriented and targeted. 


\section{REFERENCES}

1. Popim RC, Corrente JC, Marino JAG, Souza CA. Câncer de pele: uso de medidas preventivas e perfil demográfico de um grupo de risco na cidade de Botucatu. Ciênc. saúde coletiva. 2008:13:1331-6.

2. Roewert-Huber J, Lange-Asschenfeldt B, Stockfleth E, Kerl H. Epidemiology and aetiology of basal cell carcinoma. Br J Dermatol. 2007;157:47-51.

3. Kopke LFF, Schmidt SM. Basal cell carcinoma. An Bras Dermatol. 2002;77:249-85.

4. Sociedade Brasileira de Dermatologia. Análise de dados das campanhas de prevenção ao câncer da pele promovidas pela Sociedade Brasileira de Dermatologia de 1999 a 2005. An Bras Dermatol. 2006;81:533-9.

5. Estrada JG. Non-melanoma skin cancer in the Mediterranean area. Eur J Dermatol. 2007;44:922-4.

6. Rocha FP, Menezes AMB, Almeida JHL, Tomasi E. Especificidade e sensibilidade de rastreamento para lesōes cutâneas pré-malignas e malignas. Rev Saúde Pública. 2002;36:101-6.

7. Amaral ACN, Azulay RD, Azulay DR. Neoplasias epiteliais. In: Azulay RD, Azulay DR, editores. Dermatologia. 4th ed. Rio de Janeiro: Guanabara Koogan S.A.; 2006. p. 510-26.

8. Staples MP, Elwood M, Burton RC, Williams JL, Marks R, Giles GG. Non-melanoma skin cancer in Australia: the 2002 national survey and trends since 1985. Med J Aust. 2006 ; 184:6-10.
9. Dimatos DC, Duarte F0, Machado RS, Vieira VJ, Vasconcellos ZAA, Binsely J, Neves RD. Melanoma cutâneo no Brasil. Arq Catar Med. 2009;38:14-9.

10. Naser N. Cutaneous melanoma: a 30-year-long epidemiological study conducted in a city in southern Brazil, from 1980-2009. An Bras Dermatol. 2011;86:932-41.

11. Wainstein AJA, Belfort FA. Conduta para o melanoma cutâneo. Rev Col Bras Cir. 2004; 31:204-14.

12. Miller AJ, Mihm MC. Melanoma. N Engl J Med. 2006;355:51-65

13. Chinem VP, Miot HA. Epidemiology of basal cell carcinoma. An Bras Dermatol. 2011;86:292-305.

14. Mantese SAO, Berbert ALCV, Gomides MDA, Rocha A. Basal cell Carcinoma Analysis of 300 cases observed in Uberlândia - MG, Brazil. An Bras Dermatol. 2006:81:136-42.

15. Poziomczyk CS, Köche B, Dornelles MA, Dornelles SIT. Pain evaluation in the cryosurgery of actinic keratoses. An Bras Dermatol. 2011;86:645-50.

16. Roewert-Huber J, Lange-Asschenfeldt B, Stockfleth E, Kerl H. Epidemiology and aetiology of basal cell carcinoma. Br J Dermatol. 2007;157:47-51.

17. Inca.org [Internet]. Ministério da Saúde. Instituto Nacional de Câncer. Estimativas 2008: Incidência de Câncer no Brasil. Rio de Janeiro: Instituto Nacional de Câncer; 2007. 94 p. [cied 2008 Nov 12]. Available from: http://www.inca.gov.br/ estimativa/2008/versaofinal.pdf.

\section{AUTHORS'CONTRIBUTIONS}

Hudson Dutra Rezende O ID ORCID 0000-0002-7039-790X

Conception and planning of the study; Elaboration and writing of the manuscript; Obtaining, analyzing and interpreting the data; Intellectual participation in propaedeutic and/or therapeutic conduct of the cases studied; Critical review of the literature
Ana Paula Moura de Almeida
0000-0003-1297-9298

Statistical analysis; Approval of the final version of the manuscript; Conception and planning of the study; Effective participation in research orientation; Intellectual participation in propaedeutic and/or therapeutic conduct of the cases studied; Critical review of the manuscript
Eduardo Shimoda
(iD) ORCID 0000-0001-6544-687X

Statistical analysis; Approval of the final version of the manuscript; Conception and planning of the study; Effective participation in research orientation; Critical review of the manuscript Ana Carolina Xavier Milagre (ID) ORCID 0000-0003-3198-202X

Conception and planning of the study; Elaboration and writing of the manuscript; Obtaining, analyzing and interpreting the data; Critical review of the literature

Liana Moura de Almeida $\quad$ (iD) ORCID 0000-0002-7183-6900

Approval of the final version of the manuscript; Effective participation in research orientation; Intellectual participation in propaedeutic and/or therapeutic conduct of the cases studied; Critical review of the manuscript

How to cite this article: Rezende HD, Almeida APM, Shimoda E, Milagre ACX, Almeida LM. Study of skin neoplasms in a university hospital: integration of anatomopathological records and its interface with the literature. An Bras Dermatol. 2019;94(1):42-6. 